\title{
PHYSICAL AND MECHANICAL PROPERTIES OF PANEL BASED ON OUTER BARK PARTICLES OF WHITE BIRCH: MIXED PANELS WITH WOOD PARTICLES VERSUS WOOD FIBRES
}

\author{
PROPIEDADES FÍSICAS Y MECÁNICAS DE PANELES A BASE DE \\ PARTÍCULAS DE CORTEZA EXTERNA DE ABETO BLANCO: MEZCLA \\ DE PANELES CON PARTÍCULAS DE MADERA VERSUS \\ FIBRA DE MADERA
}

Roger Pedieu ${ }^{1}$, Bernard Riedl ${ }^{2}$, André Pichette ${ }^{3}$

\begin{abstract}
The use of outer white birch bark in canoes is an example of its oldest use by the first nations in Canada. This use confirms the hydrophobic characteristics of this bark, which can be capitalized on by using it in the outer layers of three-layer mixed composite panels in order to protect them from water infiltration from their surface. These panels were made up of outer white birch bark particles in the surface layers with coarse wood particles or wood fibres in the core layer. A factorial experiment used in a complete block design permitted to carry a suitable statistical analysis of measured properties. The two main considered factors were respectively the bark percentages in the surface layers with three levels and the type of material used in the core with two levels. Four replicates were done for each panel. The panels with wood particles in the core layer gave physical and mechanical properties satisfying the indoor requirements for particleboards and those with wood fibres in the core layer passed the requirement of medium fibres density board. Panel with $45 \%$ bark particles in the surface and $55 \%$ wood particles in the core was selected as the best because of its good dimensional stability.
\end{abstract}

Keywords: Hydrophobic bark composite, mechanical and physical properties, mixed panels.

\section{RESUMEN}

El uso de la corteza externa de abeto blanco en la fabricación de canoas por las primeras naciones de Canadá es un ejemplo de su uso más antiguo. Esto confirma sus características hidrófugas, la cual puede ser explotada mediante su uso en la superficie del panel compuesto de 3 capas para protegerlo de filtraciones de humedad. Estos tableros fueron fabricados con partículas de corteza externa en las capas superficiales, y con partículas gruesas o fibras de madera en el corazón. Un experimento factorial en un diseño de bloque completo hizo posible realizar el diseño de experimento. Los dos grandes factores considerados, fueron el porcentaje de corteza en las capas superficiales con 3 niveles y el tipo de material usado en el corazón, con dos niveles respectivamente (partículas y fibras de madera). Cuatro réplicas fueron hechas para cada panel. Sólo los tableros con partículas gruesas de madera en el corazón pasaron todas las pruebas físicas satisfaciendo los requerimientos del interior de los tableros de partículas. Paneles con $45 \%$ de partículas de corteza en la superficie y 55\% de partículas de madera en el corazón fueron seleccionados como los mejores, debido a su buena estabilidad dimensional.

Keywords: compuesto hidrofóbica de corteza, propiedades físicas y mecánicas, paneles mixtos.

\footnotetext{
${ }^{1}$ PH.D. Student Université Laval. Centre de Recherche sur le Bois (CRB), Université Laval, G1K7P4 Québec (Qc) Canada

${ }^{2}$ Senior Professor Université Laval. Centre de Recherche sur le Bois (CRB), Université Laval, G1K7P4 Québec (Qc) Canada

${ }^{3}$ Senior Professor Département des sciences fondamentales, Université du Québec à Chicoutimi, Québec Canada G7H 2B1

Corresponding author: Bernard.Riedl@sbf.ulaval.ca

Received: 19.03.2008. Accepted: 26.09.2008.
} 


\section{INTRODUCTION}

White birch (Betula papyrifera) bark has two different parts (Figure1). The outer bark has a paperlike texture with several layers. The inner bark has a granular form. The acidity ( $\mathrm{pH}$ value and buffering capacity) of these two parts of white birch bark is also different (Pedieu et al. 2008). In the case of this research, they were systematically separated by screening before being used in the manufacture of mixed panels.

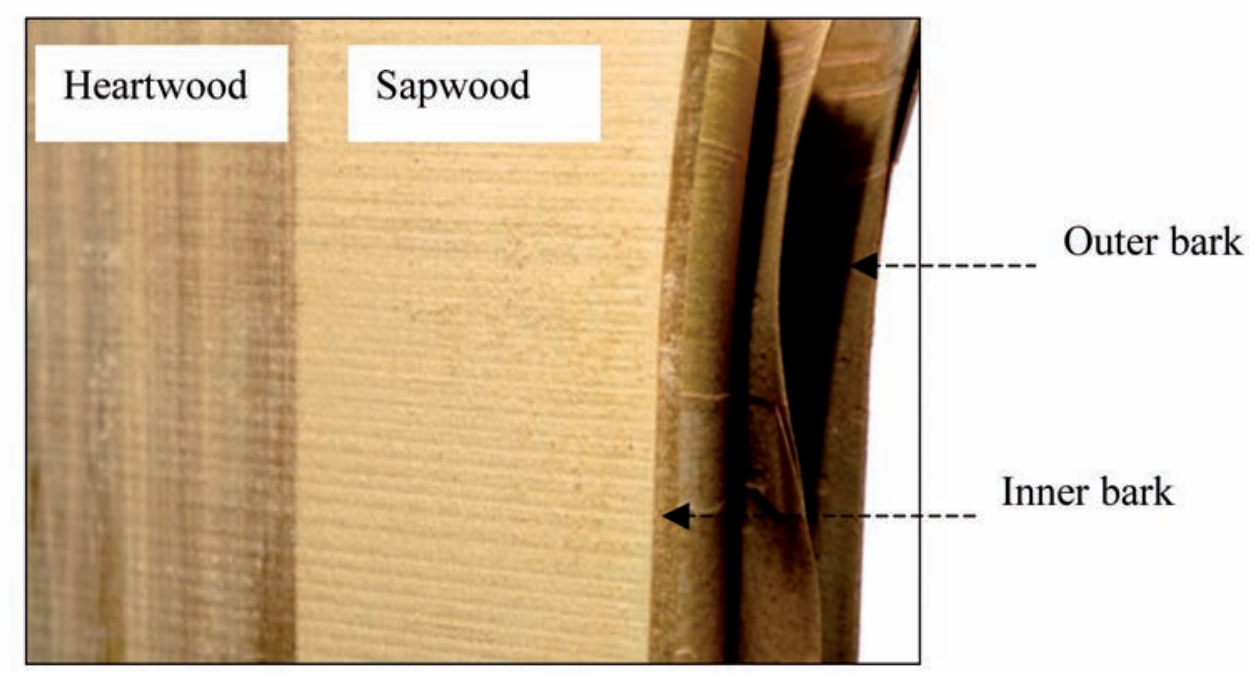

Figure 1 Photo of white birch wood section showing inner bark and outer bark

With an increasing demand of wood composite products (Sellers 2000), wood even in wood-rich Canada, will become less available and the best alternative will be to use value-added products like barks or agricultural and recycled residues (Sampathrajan et al. 1992, Kozlowski and Helwig 1998, Roffael et al. 2003). For instance, Boquillon et al. (2004) investigated the properties of wheat straw particleboards bonded with different types of resin. Interest has burgeoned in combining wood and other raw material into composite products that can utilize recycled materials (Youngquist et al. 1993a, 1993b, 1994). Birch bark is also used as folk medicines. If it is known that barks have some advantages over wood when used as a mulch or in other soil amelioration approaches (Allison 1965), it is not the same situation with respect to its utilization in particleboard manufacture because of poor mechanical properties of those particleboards (Blanchet 2000, Villeneuve 2004). In the case of this study the outer bark of white birch, a residue from parquet manufacture was used for panel manufacture at the laboratory scale. It is well known that birch outer bark is not a structural material like wood, because it has less than 4\% cellulose (Lundqvist and Back 1976). During the preliminary tests single layer panels with white birch outer bark particles were fabricated, but their mechanical properties were lower than the requirements of M-1 grade panels for interior use. Only their thickness swelling after 24 hours water immersion was good (lower than 3\%), confirming the hydrophobic characteristics of white birch outer bark. Indeed, the outer bark of white birch is hydrophobic because it is covered with waxy cuticle (suberin) impermeable to water (Fengel and Wegener 1989).

A factorial experimental design with two factors was set up for this study. The first factor was the type of structural material in the core layer of mixed panel. It was a qualitative factor with two levels: 1) coarse wood particles, 2) wood fibres. The second factor was the ratio of white birch outer bark particles in the surface layers. This factor was rather quantitative with three levels: 1) 35\%, 2) 40\%, 3) 45\% (by weight). The objective of the present research project was to create a panel using white birch bark 
that would exceed the requirements for M-1 grade particleboard as specified by the ANSI standard, then to measure their physical and mechanical properties and finally to select the best panel with the help of statistical analysis carried out in a randomized complete block design.

\section{MATERIALS AND METHODS}

\section{White birch outer bark particles preparation}

The barks were obtained from the sawmill of Thomas Louis Tremblay Inc. of Ste-Monique, located in the North of Québec, Canada. The proportion of sapwood in those barks was approximately $8 \%$ of their oven-dry weight. They were dried at room temperature for ten days to $9 \%$ moisture content and then reduced to bark particles with the help of a hammer mill (Jeffrey) and refiner (Pallmann). The inner bark was separated from the outer one by screening. The dust was eliminated by the means of a $0.25 \mathrm{~mm}$ mesh vibrating horizontal screen. The size of inner bark particles finally obtained was between $0.25 \mathrm{~mm}$ and $1 \mathrm{~mm}$. They were dried to $3 \%$ moisture content in a laboratory-type dryer. The black spruce fibres used were obtained form Uniboard Canada Inc, MDF La-Baie, Ville-de-la-Baie, Québec, Canada. The wood particles used (a mixture of spruce, fir and pine) were obtained from TAFISA in Lac-Mégantic, Québec, Canada.

\section{Preliminary Tests}

Lundqvist and Back (1976) suggested in their studies that, since it is impossible to produce panels with $100 \%$ outer birch bark particles meeting the standard requirements of M-1 grade particleboard, it is therefore advisable to use them rather in the core of mixed panels with wood particles in the surface layers. This suggestion was applied during the preliminary tests, where two sizes of white birch bark particles were used in the core of mixed panels with wood particles in the surface layers. The first panel was fabricated using outer bark particles of white birch of sizes between $2 \mathrm{~mm}$ and $6 \mathrm{~mm}$ in the core layer and fine wood particles in the surface layers. The second type of panel was fabricated using bark particles of sizes between $0.25 \mathrm{~mm}$ and $1 \mathrm{~mm}$ in the core layer and fine wood particles in the surface layers. The third type of panel was fabricated using bark particles of sizes between $0.25 \mathrm{~mm}$ and $1 \mathrm{~mm}$ in the surface layers and coarse wood particles in the surface layers. The modulus of rupture (MOR) and the modulus of elasticity (MOE) of the first and second panels did not meet the standard requirements of M-1 grade particleboard. But the MOE and MOR of the third panel passed the above mentioned standards.

\section{Experimental Design}

The above described preliminary tests enabled to set up a 3-layer mixed panel with white birch outer bark particles in the surface layers and coarse wood particles in the core layer or with white birch outer bark particles in the surface layers and wood fibres in the core layer. The target density was 750 $\mathrm{kg} / \mathrm{m}^{3}$ and the nominal thickness $11 \mathrm{~mm}$. A factorial design with two manufacturing factors in a complete block design (CBD) was used. Blocking was used to prevent nuisance factors from known and controllable sources of variability (Montgomery 2005).

The first factor of the experiment was the type of material used in the core layer. This factor has two levels: wood fibres and wood particles. The second factor is the percentage of white birch outer bark particles used in the surface layers with three levels: 45, 40 and 35\% (of oven-dry weight material used for the panel manufacture). The choice of these three percentages was made from the preliminary tests as follows: with more than $45 \%$ white birch outer bark particles in the surface layers, the modulus of rupture and the modulus of elasticity of manufactured panel were weak and with less than $35 \%$ white birch outer bark particles in the surface layers, the thickness swelling of manufactured panel was high. The total panel types in each block resulted from the multiplication of both factor levels, that is to say $2 \times 3=6$ panel types. Each panel considered as an experimental unit was replicated four times to give a total of 24 panels. 
The identification of the six treatments corresponding to six panel types per block is presented in Table 1. The experimental design was set up with the help of a plan procedure of SAS software to fulfill the randomisation principle that eliminates subjectivity and ensure the independency of errors.

Table 1. Description of Panels' Types

\begin{tabular}{|l|l|l|}
\hline$\#$ & Types & \multicolumn{1}{|c|}{ Description } \\
\hline 1 & $\mathrm{P}_{\mathrm{p}-35}$ & $\begin{array}{l}\text { Wood particles in the core layer. White birch outer bark particles in the } \\
\text { surface layers is 35\% (by weight of oven-dry material used) }\end{array}$ \\
\hline 2 & $\mathrm{P}_{\mathrm{p}-40}$ & $\begin{array}{l}\text { Wood particles in the core layer. White birch outer bark particles in the } \\
\text { surface layers is } 40 \% \text { (by weight of oven-dry material used) }\end{array}$ \\
\hline 3 & $\mathrm{P}_{\mathrm{p}-45}$ & $\begin{array}{l}\text { Wood particles in the core layer. White birch outer bark particles in the } \\
\text { surface layers is } 45 \% \text { (by weight of oven-dry material used) }\end{array}$ \\
\hline 4 & $\mathrm{P}_{\mathrm{f}-35}$ & $\begin{array}{l}\text { Wood fibres in the core layer. White birch outer bark particles in the } \\
\text { surface layers is 35\% (by weight of oven-dry material used) }\end{array}$ \\
\hline 5 & $\mathrm{P}_{\mathrm{f}-40}$ & $\begin{array}{l}\text { Wood fibres in the core layer. White birch outer bark particles in the } \\
\text { surface layers is 40\% (by weight of oven-dry material used) }\end{array}$ \\
\hline 6 & $\mathrm{P}_{\mathrm{f}-45}$ & $\begin{array}{l}\text { Wood fibres in the core layer. White birch outer bark particles in the } \\
\text { surface layers is 45\% (by weight of oven-dry material used) }\end{array}$ \\
\hline
\end{tabular}

\section{Panels Manufacture and Tests}

The manufacturing parameters are listed in Table 2. The particles for each panel type were mixed in a rotating-drum mixer for 5minutes. During blending of wood fibres, fibre packets or balls were formed. These balls were eliminated by passing fibres through the refiner (Pallmann). Based on oven-dry mass of wood fibres used in the core layer, $14 \%$ of urea-formaldehyde resin (the normal percentage of UF in the MDF industries is between 10 and 12\%) were used to resinate these fibres in order to make up for losses of this resin during the elimination of fibres packets through the Pallmann refiner. Garcia et al. (2005) used the same percentage of UF to blend fibres for MDF manufacture in their research project. The panels were manually formed in a frame prior to their pressing. The panels were conditioned at a temperature of $20^{\circ} \mathrm{C}$ and $65 \%$ relative humidity until they reached their equilibrium moisture content (two weeks). Then they were sanded to $11 \mathrm{~mm}$ final thickness before any test was carried out. Photos of manufactured panels are presented in Figure 2.

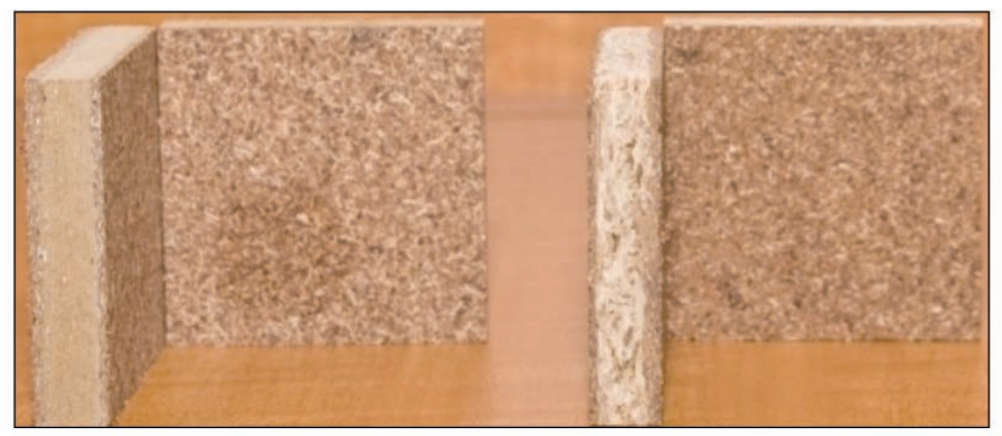

Figure 2. Photos of panels, from left to right: mixed panel with outer bark of white birch in the face and wood fibres in the core; mixed panel with outer bark of white birch in the face and wood particles in the core 
Table 2. Manufacturing Parameters

\begin{tabular}{|c|c|}
\hline $\begin{array}{l}\text { Board size (width } \times \text { length } \times \\
\text { thickness) }\end{array}$ & $\begin{array}{l}0.56 \mathrm{~m} \times 0.46 \mathrm{~m} \times 0.012 \mathrm{~m} \text { (non-sanded) and } \\
0.56 \mathrm{~m} \times 0.46 \mathrm{~m} \times 0.011 \mathrm{~m} \text { (sanded) }\end{array}$ \\
\hline Target board density & $750 \mathrm{kgm}^{-3}$ \\
\hline Compaction ratio $(\mathrm{Cr})^{*}$ & $\begin{array}{l}5.4 \text { for mixed panels with wood particles in the core, } 7 \\
\text { for mixed panel with wood fibres in the core. }\end{array}$ \\
\hline Shelling ratio** & $\begin{array}{l}35,40 \text { or } 45 \% \text { (based on oven-dry weight of outer bark } \\
\text { particles of white birch) for all mixed panels }\end{array}$ \\
\hline Press plates temperature & $180^{\circ} \mathrm{C}$ \\
\hline Press pressure & $180 \mathrm{KPa}$ \\
\hline Resin used & $\begin{array}{l}\text { Urea formaldehyde (Borden Casco-Resin TL-105, solid } \\
\text { content: } 65 \% \text { ). } \\
11 \% \text { UF (based on oven-dry weight of outer bark } \\
\text { particles ) used for surface layers with bark particles, } 7 \% \\
\text { UF used for core layer with coarse wood particles and } \\
14 \% \text { UF for core layer with wood fibres }\end{array}$ \\
\hline $\begin{array}{l}\text { Catalyst added to UF used } \\
\text { in the core }\end{array}$ & $\begin{array}{l}\text { Ammonium chloride } 30 \% \text { ( } 30 \mathrm{~g} \text { of } \mathrm{NH}_{4} \mathrm{CL} \text { dissolved in } \\
100 \mathrm{ml} \text { distilled water) }\end{array}$ \\
\hline Wax & $\begin{array}{l}0.5 \% \text { (based on oven-dry weight of material used in the } \\
\text { core layer). No wax was used in the outer bark particles } \\
\text { of white birch because they are already waxy }\end{array}$ \\
\hline Press closing time & 26 seconds \\
\hline Curing time & 4 minutes \\
\hline Press opening time & 1 minute in three steps \\
\hline
\end{tabular}

${ }^{*} \mathrm{Cr}=$ mat thickness/panel thickness, ${ }^{* *}$ Shelling ratio = proportion (by oven-dry weight) of surface layers

\section{Determination of Mechanical and Physical Properties}

Tests samples were prepared based on ASTM D-1037-99, and the result of each test was compared with the value of ANSI A208.1-1999 and ANSI A208.2-2002. Vertical density profiles were determined from internal bond samples with a QMS X-ray density profiler, Model QDP-01X. The surface density was obtained from the maximum density point, and the core density was obtained from the minimum point of each respective zone of the vertical density profile. The modulus of elasticity (MOE) and the modulus of rupture (MOR) were obtained from an average of three $314 \times 75 \mathrm{~mm}$ samples for each panel. Internal bond (IB) was obtained from an average of five $50 \times 50 \mathrm{~mm}$ samples for each panel. Thickness swelling (TS) and water soaking (WA) were obtained from an average of two $150 \times 150 \mathrm{~mm}$ samples for each sample. Linear expansion (LE) was obtained from an average of two $150 \times 75 \mathrm{~mm}$ samples for each panel. LE was measured following a desorption from 65 to $50 \%$ relative humidity (RH) and an adsorption from 50 to $80 \% \mathrm{RH}$. The RH conditions were obtained using a climatic chamber, model N0. WM - 906 - MP2H - 5 - SC/WC from Cincinnati Sub-Zero (CSZ).

LE was calculated as follows:

$$
\mathrm{LE}=\left[\left(\mathrm{L}_{2}-\mathrm{L}_{1}\right) / \mathrm{L}_{1}\right] \times 100,
$$

where LE is the linear expansion between 50 and $80 \% \mathrm{RH}(\%) ; \mathrm{L}_{1}$ is the sample length at equilibrium of $50 \% \mathrm{RH}(\mathrm{mm}) ; \mathrm{L}_{2}$ is the final sample length after reconditioning to $80 \% \mathrm{RH}(\mathrm{mm})$. 


\section{RESULTS AND DISCUSSION}

\section{Density Profile}

The produced panels presented the typical density profile expected by mat densification. Namely, higher density was obtained near the panel face, while the panel core layer displayed a low density plateau. The density profiles of panels with wood particles in the core were similar and those of panels with wood fibres in the core were also similar. Therefore, only one profile from each group was selected and presented in Figure 3. The core layer of panel with wood fibres in the core displayed the highest value of density because the compression ratio of that panel is higher than that of panel with wood particles in the core layer.

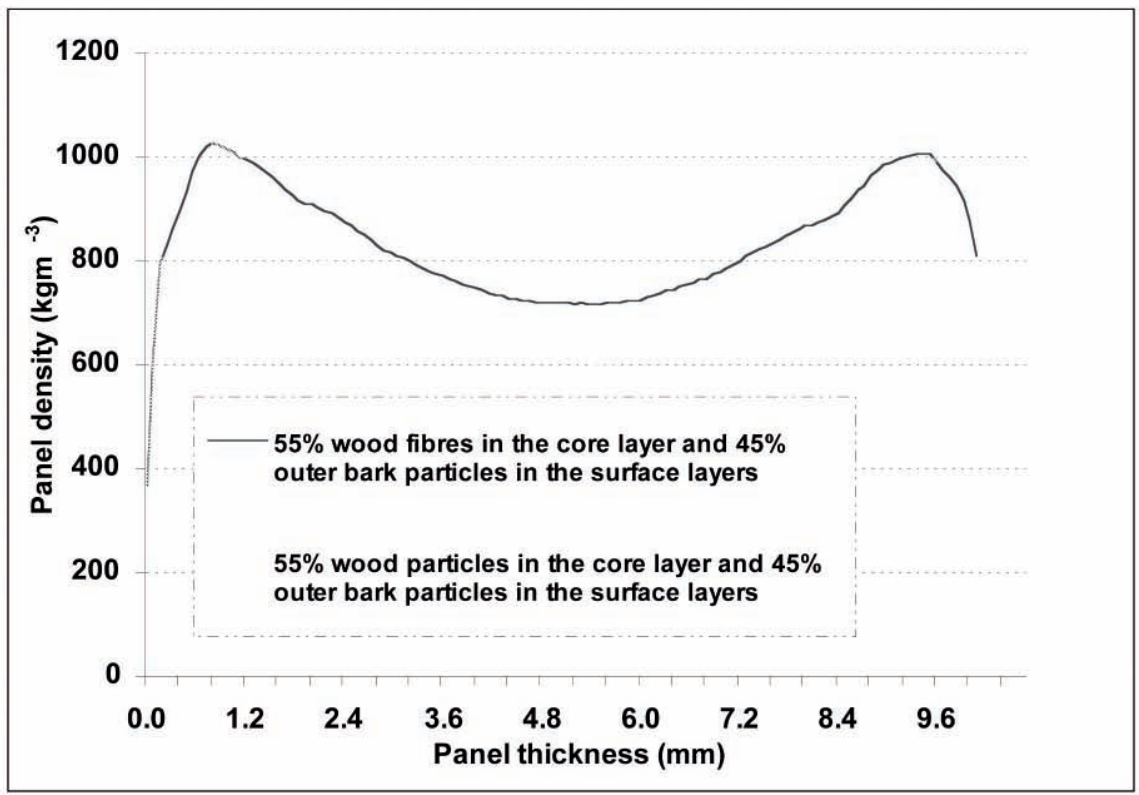

Figure 3. Typical density profiles of mixed panel with white birch outer bark particles in the surface layers and wood particles or wood fibres in the core layer

\section{Analysis of Variance}

The summary of analysis of variance (ANOVA) is presented in Table 3. The F values associated to treatments for all tested properties were significant but the $\mathrm{F}$ value associated to blocking for each tested property was not significant. 
Table 3. Summary of Variance Analysis (ANOVA).MOR = modulus of rupture, $\mathrm{MOE}=$ modulus of elasticity, IB= internal bond, $\mathrm{TS}=$ thickness swelling, $\mathrm{LE}=$ linear expansion

\begin{tabular}{|c|c|c|c|c|c|c|}
\hline \multirow[t]{2}{*}{ Source of Variation } & \multicolumn{6}{|c|}{ Mechanical and physical properties (F values) } \\
\hline & df & MOR & MOE & IB & TS & LE \\
\hline Blocks & 3 & $1.30 \mathrm{~ns}$ & $0.71 \mathrm{~ns}$ & $1.35 \mathrm{~ns}$ & $2.38 \mathrm{~ns}$ & $0.50 \mathrm{~ns}$ \\
\hline Wm & 1 & $81.86^{* *}$ & $61.09^{* *}$ & $109.87^{* *}$ & $13.24 * *$ & $284.78^{* *}$ \\
\hline$\%$ & 2 & $14.52 * *$ & $51.88^{* *}$ & $19.09^{* *}$ & $0.92 \mathrm{~ns}$ & $9.24 * *$ \\
\hline $\mathrm{Wm} \times \%$ & 2 & $4.53^{*}$ & $0.85 \mathrm{~ns}$ & $6.59^{* *}$ & $39.87 * *$ & $4.50^{*}$ \\
\hline \multicolumn{7}{|l|}{$\begin{array}{l}\text { Contrasts(simple } \\
\text { comparisons) }\end{array}$} \\
\hline Wm & 1 & $81.86^{* *}$ & $61.09 * *$ & $109.87^{* *}$ & $13.24 * *$ & $284.78^{* *}$ \\
\hline$\% \mathrm{~L}$ & 1 & $28.78 * *$ & $100.44 * *$ & $37.84^{* *}$ & $0.65 \mathrm{~ns}$ & $13.23^{* *}$ \\
\hline$\% Q$ & 1 & $0.27 \mathrm{~ns}$ & $15.32 * *$ & $0.34 \mathrm{~ns}$ & $1.19 \mathrm{~ns}$ & $5.25^{*}$ \\
\hline$w m \times \% L$ & 1 & $8.46^{*}$ & $1.65 \mathrm{~ns}$ & $12.09^{* *}$ & $0.98 \mathrm{~ns}$ & $5.36^{*}$ \\
\hline $\mathbf{w m} \times \% Q$ & 1 & $0.59 \mathrm{~ns}$ & $0.05 \mathrm{~ns}$ & $1.09 \mathrm{~ns}$ & $78.75 * *$ & $3.65 \mathrm{~ns}$ \\
\hline
\end{tabular}

$\mathbf{d f}=$ degree of freedom, wm $=$ wood material in the core layer, $\%=$ percentage of white birch outer bark particles in the surface layers. $\% \mathbf{L}=$ linear effect of percentage, $\% \mathbf{Q}=$ quadratic effect of percentage, $\mathbf{w m} \times \% \mathbf{L}=$ interaction between $w \mathrm{~m}$ and $\% \mathrm{~L}, \mathbf{w m} \times \% \mathbf{Q}=$ interaction between $\mathrm{wm}$ and $\% \mathrm{Q}, \mathrm{ns}=$ non-significant, * significant at 0.05 probability level ** significant at 0.01 probability level.

\section{Mechanical and Physical Properties \\ Modulus of Elasticity}

The results obtained for the modulus of elasticity (MOE) are presented in Figure 4. The MOE of all panels with coarse wood particles in the core layer met the requirements of grade M-1 particleboard for interior use and the MOE of panels with wood fibres in the core layer passed the grade 120 requirements for MDF. The interaction between the type of wood material (wm) in the core layer and the percentage $(\%)$ of white birch outer bark particles used in the surface layers was not significant although the effects of wood material in the core layer and the effect of the variation of bark particles percentage in the surface layer were highly significant (Table 3). The MOE of mixed panels decreases with an increase of white birch bark particles percentage in the core layer. The highest value of MOE is obtained with Pp-35 (panel with coarse wood particles in the core layer and 35\% white birch outer bark particles in the surface layers). 


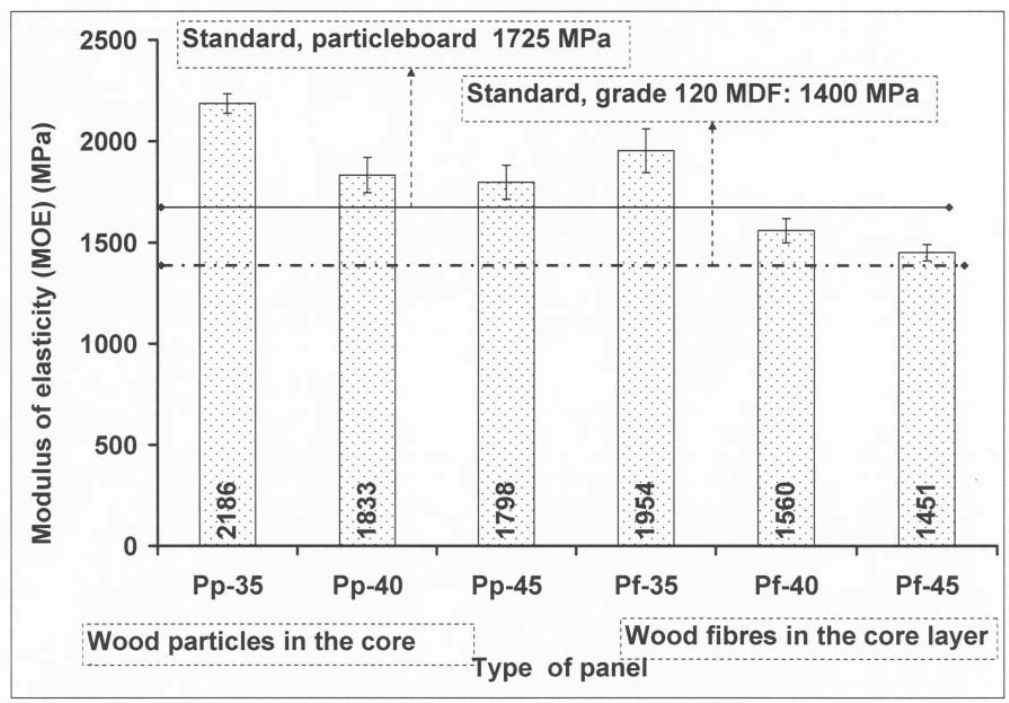

Figure 4. Modulus of elasticity [MOE] (mean values and standard deviations)

\section{Modulus of Rupture}

The results obtained for the modulus of rupture (MOR) are presented in Figure 5. The MOR of all panels with coarse wood particles in the core layer met the requirements of grade M-1 particleboard for interior use and the MOR of panels with wood fibres in the core layer passed the grade 120 requirements for MDF. The interaction between the type of wood material (wm) in the core layer and the linear percentage $(\% \mathrm{~L})$ of white birch outer bark particles used in the surface layers was significant (Table $3)$. Therefore the highest MOR values were obtained when wood fibres were used in the core layer of mixed panels and when the percentage of white birch outer bark particles in the surface layers was the lowest. The highest value of MOR was obtained with Pf-35 (panel with wood fibres in the core layer and $35 \%$ white outer bark particles in the surface layers) (Figure 5).

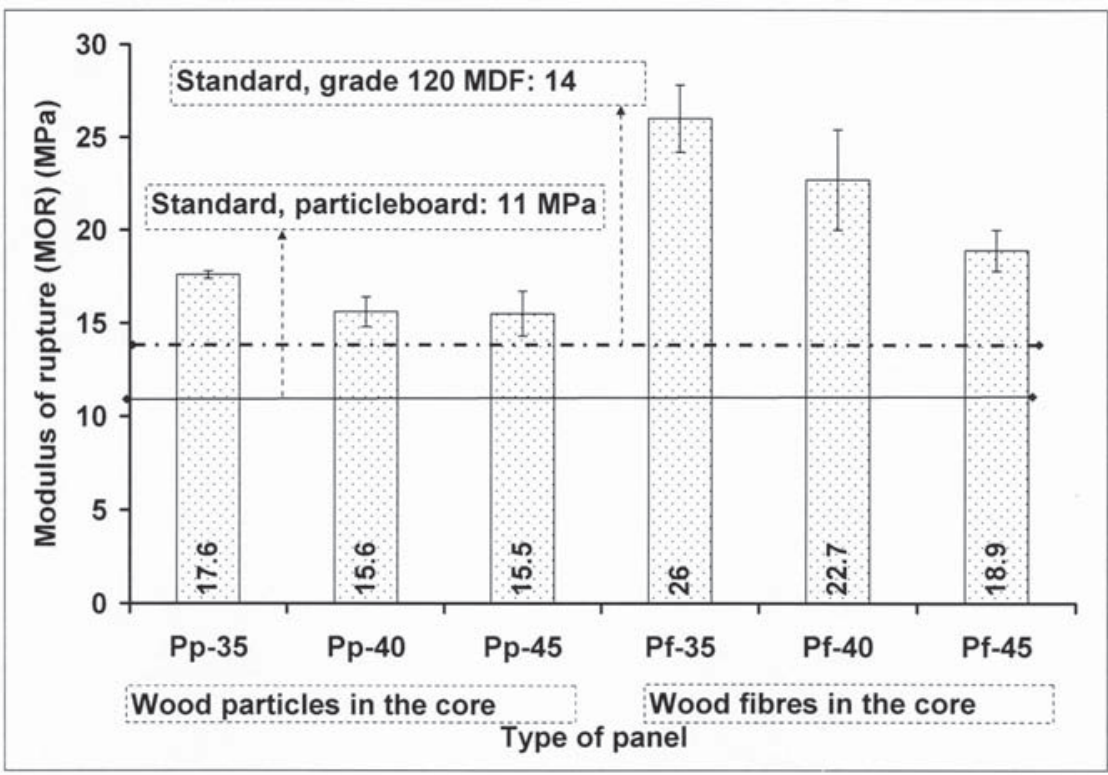

Figure 5. Modulus of rupture [MOR] (mean values and standard deviations) 


\section{Internal Bond}

The results obtained for the internal bond (IB) are presented in Figure 6. The IB of all panels with coarse wood particles in the core layer met the requirements of grade M-1 particleboard for interior use and the IB of panels with wood fibres in the core layer passed the grade 120 requirements for MDF. The interaction between the type of wood material $(\mathrm{wm})$ in the core layer and the linear percentage $(\% \mathrm{~L})$ of white birch outer bark particles used in the surface layer was significant (Table 3). Therefore the highest IB values were obtained when wood particles were used in the core layer of mixed panels and when the percentage of white birch outer bark particles in the surface layers was the lowest. The highest value of MOR is obtained with Pp-35 (panel with wood particles in the core layer and 35\% white outer bark particles in the surface layers) (Figure 6)

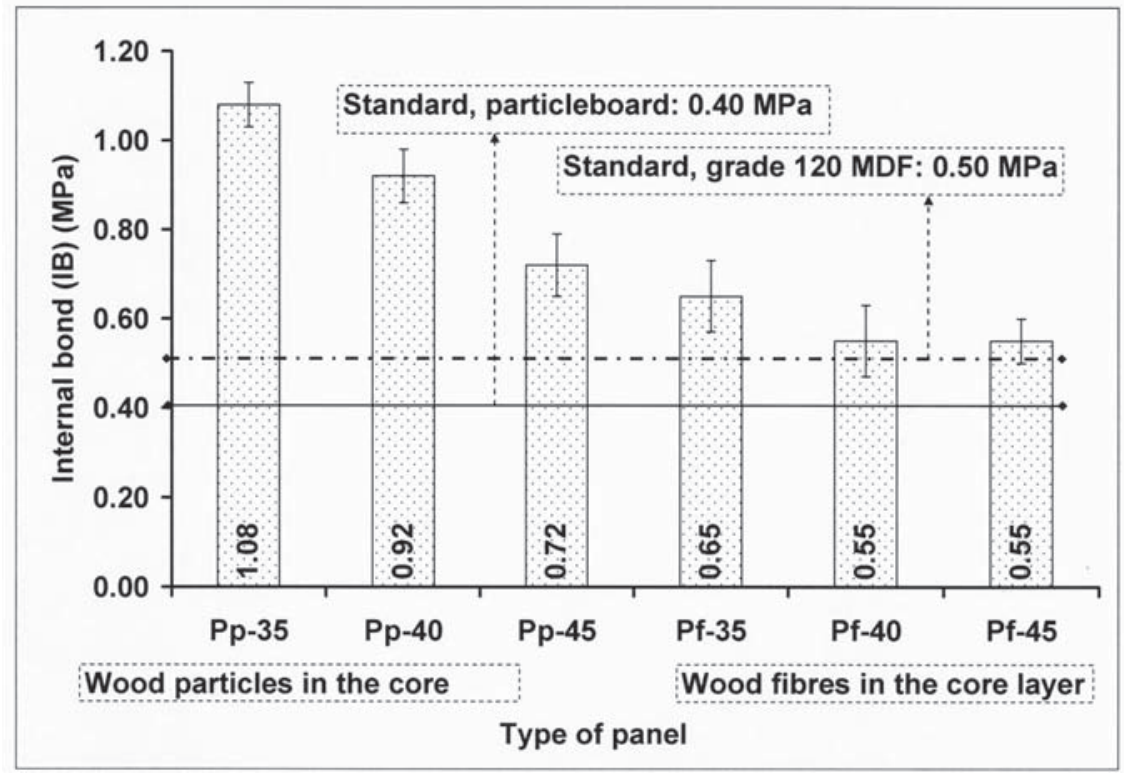

Figure 6. Internal bond [IB] (mean values and standard deviations)

\section{Thickness Swelling}

The results obtained for the thickness swelling (TS) are presented in Figure 7. There is no specification for the TS for M-1 grade particleboard. The TS of panels with wood fibres in the core layer passed the grade 120 requirements for MDF. [The specification of TS according to ANSI A208.2-2002 is normally $1.5 \mathrm{~mm}$ for grade $120 \mathrm{MDF}$. Its corresponding value in percentage which is $100 \times(1.5 / 11)=$ $13.6 \%$ was used in this study. $11 \mathrm{~mm}$ is the panel thickness]. The interaction between the type of wood material $(\mathrm{wm})$ in the core layer and the quadratic percentage $(\% \mathrm{Q})$ of white birch outer bark particles used in the surface layer was significant (Table 3). Therefore the lowest TS value was obtained when wood particles were used in the core layer of mixed panel and when the percentage of white birch outer bark particles in the surface layers was $45 \%$ (Figure 7). 


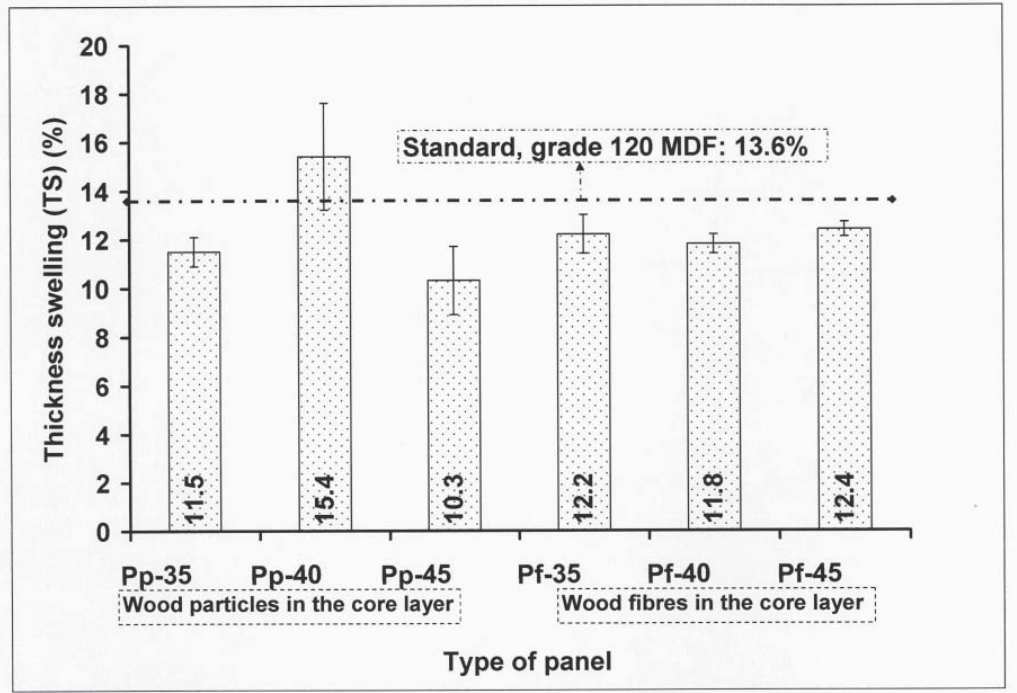

Figure 7. Thickness swelling [TS] (mean values and standard deviations)

\section{Linear Expansion}

The results of linear expansion (LE) are presented in Figure 8. The LE of all panels with coarse wood particles in the core layer met the requirements of grade M-1 particleboard for interior use. There is no specification for LE for grade $120 \mathrm{MDF}$. The interaction between the type of wood material (wm) in the core layer and the linear percentage $(\% \mathrm{~L})$ of white birch outer bark particles used in the surface layer was significant (Table 3). The LE values of panels with coarse wood particles in the core layer were smaller than those of panels with wood fibres in the core layer. The smallest and best value of LE was obtained when wood particles were used in the core layer of mixed panels and when the percentage of white birch outer bark particles in the surface layers was either $40 \%$ or $45 \%$.

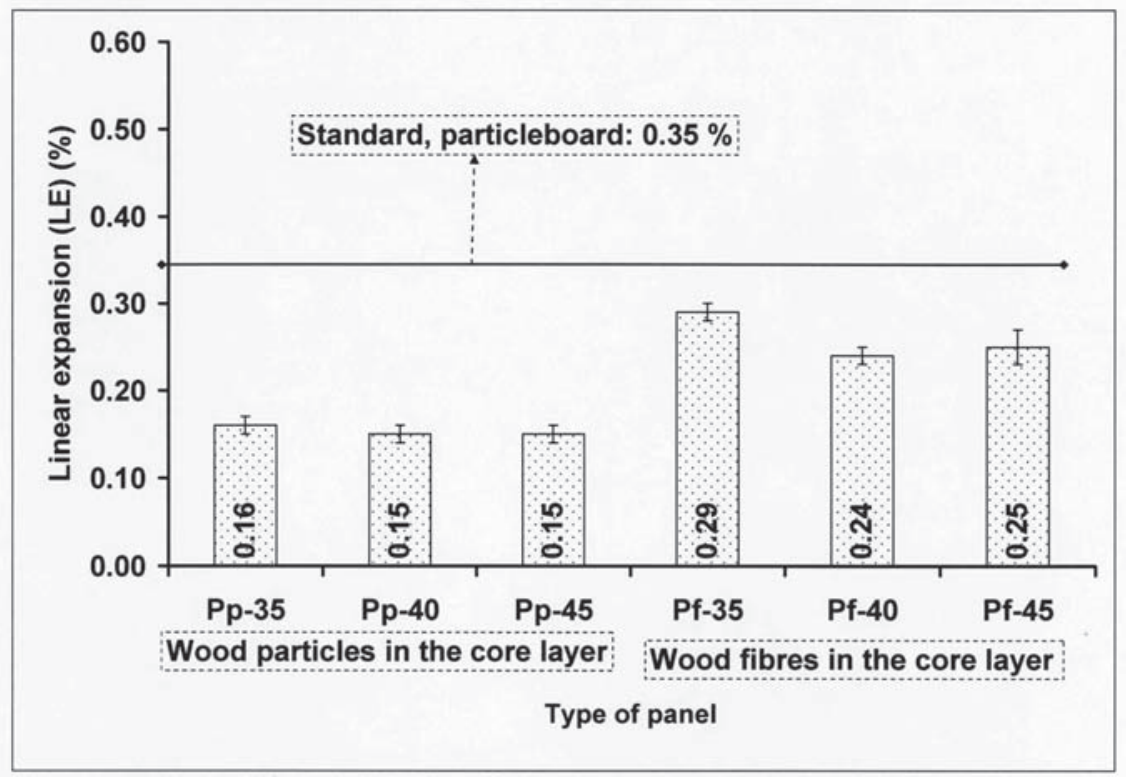

Figure 8. Linear expansion [LE] (mean values and standard deviations) 


\section{CONCLUSION AND RECOMMENDATIONS}

1. All mixed panels with coarse wood particles in the core layer and fine white birch outer bark particles in the surface layers met the requirements of grade M-1 particleboard for interior use and mixed panels with wood fibres in the core layer and fine white birch outer bark particles in the surface layers passed the grade 120 requirements for MDF.

2. The best panel selection was done especially by taking into account the dimensional stability and the percentage of white birch outer bark particles used in the surface layers. Therefore, the selected panel was the one with $60 \%$ coarse wood particles in the core layer and $40 \%$ white outer bark particles in the surface layers.

3. The combination of outer bark particles of white birch and wood fibres could be a possibility to lower the production cost of MDF because up till 45\% fibres (based on oven-dry fibres weight) can be substituted by low cost outer bark particles of white birch.

4. It is advised to repeat the experiment by reducing the mixed panel target density from $750 \mathrm{~kg} /$ $\mathrm{m}^{3}$ to $690 \mathrm{~kg} / \mathrm{m}^{3}$ and the percentage of UF resin in the outer bark particles of white birch from 11 to $9 \%$ in the aim of investigating the effect of these reductions on the mechanical and physical properties of new manufactured panels.

\section{ACKNOWLEDGMENTS}

The authors are grateful for the financial support provided by Fonds québécois de la recherche sur la nature et les technologies (FQRNT) and Université Laval for providing financial support for this research.

\section{REFERENCES}

Allison, F.E. 1965. Decomposition of wood and bark sawdust in soil: Nitrogen requirements and effects on plants. USDA Agr. Res. Serv. Tech. Bull. No.1332, 58 pp.

American Society for Testing and Material. 1999. Standard test methods for evaluating properties of wood-based fiber and particle panel materials. ASTM D 1037-99. ASTM Annual Book of Standards. Volume 04.10 West Conshohocken, Pa . pp.140-170.

American National Standard Institute. 1999. Particleboard ANSI A208.1-1999. 11p. ANSI

American National Standard Institute. 2002. Medium Density Fiberboard (MDF) for Interior Applications ANSI A208.2 - 2002. National Particleboard Association, USA. 11p.

Blanchet, P.; Cloutier, A.; Riedl, B. 2000. Particleboard made from hammer milled black spruce residues. Wood Sci. Technol. 34:11-19.

Boquillon, N.; Elbez, G.; Schonfeld, U. 2004. Properties of wheat straw particleboards boned with differentty peso fresin. J. Wood Sci. 50:230-235.

Fengel, D.; Wegener, G. 1989. Wood - Chemistry, Ultra structure, Reactions Walter de Gruyter. Berlin, New York: 240-267.

Garcia, R.A.; Cloutier, A.; Riedl, B. 2005. Amélioration de la stabilité dimensionnelle des panneaux MDF par traitements physico-chimiques. Thèse de doctorat Univesité Laval Québec, Canada $120 \mathrm{p}$. 
Kozlowski, R.; Helwig, M. 1998. Lignocellulosic polymer composite. In:Science and Technology of Polymer and Advanced Materials. Prasad, P.N. (Ed). Plenum Press, New York,.679-698 pp.

Lundqvist, E.K.; Back, L.E. 1976. The use of bark for wood based panels. Critical evaluation. Swedish Forest Products Research Laboratory, Stockholm. Presented at ECE/FAO, Timber Division. Symposium on extending the use of wood residues, in Bucarest, Romania, September-October 1, 1976.

Montgomery, D.C. 2005. Design and analysis of experiments. 6th Edition Arizona State University. 119-202 pp.

Pedieu, R.; Riedl, B.; Pichette, A. 2008. Measurement of wood and bark particles acidity and their impact on the curing of urea-formaldehyde resin during the hot pressing of mixed panels. Holz als Roh Werkst. 66: 113-117

Roffael, E.; Schneider, T.; Pedieu, R. 2003. Untersuchung über den teilweisen Ersatz von Strands in Oriented Strand Boards (OSB) durch unterschiedliche lignozellulosische Rohstoffe. Masterarbeit Georg-August-Universität, Göttingen, Deutschland.

Sampathrajan, A.; Vijayaraghavan, N.C.; Swaminathan, K.R. 1992. Mechanical and thermal properties of particleboards made from farm residues. Bioresour. Technol. 40, 249-251.

Sellers, T. 2000. Growing markets for engineered products spurs research. Wood Technol. 127 (3) 40-43.

Villeneuve, E. 2004. Utilisation de l'écorce du peuplier faux-tremble pour la fabrication des panneaux de particules. Mémoire de maîtrise, département des sciences du bois et de la forêt, Université Laval, Québec, Canada.

Youngquist, J.A.; English, B.E.; Spelter, H.; Chow, P. 1993a. Agriculture fibers in composition panels, in: Maloney, Thomas M., ed. Proceedings, 27th international particleboard/composite materials symposium; 1993 March30-April 1; Pullman, WA. Pullman, WA: Washington State University: $133-152$.

Youngquist, J.A.; Myers, G.E.; Muehl, J.;Krzysik, A.;Clemons, C. 1993b. Composites from recycled wood and plastics. Final Rep., U.S. Environmental Protection Agency, Project IAG DW12934608-2. Madison, WI: U.S. Department of Agriculture, Forest Service, Forest Products Laboratory.

Youngquist, J.A.; English, B.E.; Scharmer, R.C.; Chow, P.; Shook, S. R. 1994. Literature review on use of non-wood plants fibers for building materials and panels. Gen. Tech. Rep. FPL-GTR-80. Madison, WI: U.S. Department of Agriculture, Forest Service, Forest Products Laboratory. 